\title{
Mispricing of Really Dirty Surplus and the Trading Behavior of Short Sellers
}

\author{
Paul A. Griffin**, Hyun A. Hong ${ }^{\dagger}$, Ji Woo Ryou $^{\ddagger}$
}

\begin{abstract}
We study whether equity short sellers arbitrage the complexity of "really dirty surplus" (RDS) and how their trading behavior impacts others. RDS refers to accounting items that can arise when financial statements recognize equity transactions, mainly in other comprehensive income $(\mathrm{OCI})$, at other than fair value. Measured as the difference between the recognized item and its fair value, an investor cannot directly observe RDS in financial statements. Using a unique dataset on security lending, we find that shorting demand increases and shorting supply decreases for firms deemed to have low or negative RDS in their financial statements. Because the supply of shortable RDS stocks does not meet the demand, constrained short sellers who seek to arbitrage RDS face higher borrowing costs. This implies that traders in the equity shorting market impact other investors by mitigating but not eliminating quickly the potential market mispricing of RDS.
\end{abstract}

Keywords Really dirty surplus, Market mispricing, Shorting market, Other comprehensive income

JEL Classification G12, G14, G21, M41

Data Availability From public sources identified in the study.

\section{Introduction}

Several studies conclude that the ability of high short interest or high short volume to predict negative future stock returns indicates that short sellers have superior skill and expertise in acquiring and processing information compared to outside investors (Boehmer et al. 2008; Boehmer and Wu 2013; Senchack and Starks 1993). Yet, despite this work, prior research (discussed below) does not identify the exact source of short sellers' advantage. Does it come from publicly-available disclosures or private information access? In addition, the possibility that short interest or short volume represent biased or noisy proxies for shorting demand or supply may make it difficult to identify the source (Beneish et al. 2015).

In this study, we use direct and arguably cleaner proxies for shorting demand and supply, which we extract from a comprehensive and unique security lending dataset. We use these data to address the following open question: Is short selling responsive to a particular component of firm performance that is complex and costly for outside investors to understand? To study complex and costly information, we focus on a difficult-to-observe income component known as "really dirty surplus" (RDS). Specifically, we examine short sellers' ability to exploit the potential mispricing by investors of RDS in advance of its release in published financial statements. RDS refers to unreported accounting

\footnotetext{
* Graduate School of Management, University of California, Davis, California, USA 95616: pagriffin@ucdavis.edu.

† Anderson Graduate School of Management, University of California, Riverside, California, USA 92521: honghyuna@gmail.com.

‡ Robert C. Vackar College of Business \& Entrepreneurship, University of Texas Rio Grande Valley, Texas, USA 78539: jiwoo.ryou@utrgv.edu.
} 
amounts that arise when financial statements recognize equity transactions, mostly in other comprehensive income (OCI), at other than fair value. As an increasingly significant and frequent, but largely hidden component of firm performance, we predict that equity short sellers and others wanting to use their informational skill and expertise will target RDS to generate higher excess stock returns. Landsman et al. (2011) find that RDS can be used to generate negative future abnormal hedge returns. They reason that investors are optimistic (but not necessarily correct) regarding firms with large RDS losses, or that RDS associates with an unknown risk factor. Similarly, Dowdell et al. (2018) show that analysts' earnings forecasts are unnecessarily optimistic for firms with large RDS losses. The underlying mechanism generating negative hedge RDS returns, however, remains a mystery. We enrich the prior literature by testing whether informed investors such as short traders can profit (e.g., by shorting the stocks of firms with large RDS losses) by trading against other investors who might have purchased the stocks with large RDS losses. Our study may, thus, explain the negative future abnormal hedge returns from investing in stocks of firms with large RDS losses (Landsman et al. 2011). To our knowledge, we are the first to examine the potential relation between RDS and shorting market demand and supply.

When net income excludes OCI or unusual items, it is generally seen as clean-surplus net income. However, when net income includes OCI or unusual items that flow directly into retained earnings this constitutes dirty-surplus net income. Accounting rules report dirty-surplus items as OCI in the comprehensive income section and the statement of changes in shareholders' equity (Biddle and Choi 2006). RDS items, however, differ from dirty-surplus items because the former encompasses OCI or unusual items arising from equity transactions recognized at other than fair value. Transactions that can generate RDS include shares (including treasury shares) issued in a stock option exercise, a conversion of bonds into shares, an offering or repurchase of shares, and shares exchanged in mergers and acquisitions. These transactions can all result in an OCI entry that differs from its fair value. Building on the notion that RDS items and their amounts are not readily observable in annual reports (since the fair values associated with the transactions are not reported), Landsman et al. (2011) construct hypothetical hedge portfolios that yield positive and significant excess hedge returns. They conclude that equity investors do not comprehend fully the predictive value of RDS information. They find that equity investors initially overprice the lowest or most negative RDS stocks, which yields future negative stock returns. However, they do not identify a potential channel through which a price adjustment might eventually occur.

As one channel, the current study investigates whether short sellers form efficient expectations of firm value, which reduces the potential for stock mispricing from the amount and type of RDS. Short selling is the sale of equity 
securities borrowed for a fee from institutional investors, brokerages, or broker-dealers with the objective of repurchasing the borrowed shares at a lower future price. Shorting represents a significant proportion of reported daily stock trading. ${ }^{1}$ Yet, it is unknown whether short traders can generate future negative excess stock returns associated with low or negative amounts of hidden (i.e., deemed) RDS. Evidence of negative excess stock returns would be consistent with short sellers expertly analyzing this information early and with outside investors exhibiting a delayed reaction. To examine whether short traders can generate future negative excess stock returns, we focus on the predictive ability of shorting over one-year before the release of firms' financial statements. This measurement window permits us to examine whether short sellers act as if they perceive correctly the valuation implications of these deemed RDS transactions. These represent hidden and costly-to-understand components of earnings that occur throughout the fiscal year. ${ }^{2}$

Diamond (1985) and Diamond and Verrecchia (1987) provide theoretical guidance that if short selling reflects unpublicized or difficult to analyze adverse information, it should advance accurate security pricing (hereafter, the D$\mathrm{V}$ hypothesis). Building on this hypothesis, many have studied the relation between the shorting market and future stock returns (D’Avolio 2002; Diether et al. 2009; Engelberg et al. 2012; Jones and Lamont 2002). In addition, Cohen et al. (2007) find that increased shorting demand is a strong predictor of future stock returns, concluding that the shorting market is a critical channel for private information revelation. Others emphasize that supply constraints in the shorting market can impede price discovery and help predict future returns (Beneish et al. 2015; Reed 2015). Still, whether the channel of private information revelation-constrained or not-relates to analytical skill or privileged access remains unclear from the literature. Few studies identify the precise source of the advantage.

On the one hand, Griffin (2003) and Karpoff and Lou (2010) study short selling in firms under investigation for financial misconduct. They find that short sellers trade ahead of the public announcement of those investigations but not whether the trades result from access or skill. Others show that short sellers' advantage originates from their skill in extracting and processing information from public news about earnings and earnings forecasts (Beneish and Vargus 2002; Christophe et al. 2004; Christophe et al. 2010; Curtis and Fargher 2014; Engelberg et al. 2012; Hirshleifer et al. 2011). ${ }^{3}$ These studies, too, do not identify the precise source of short-sellers' advantage. For example, simply

\footnotetext{
${ }^{1}$ https://www.nyse.com/markets/reports.

2 They may acquire this information through brokerage house reports, analyst reports, new media, and firm prior-period financial statements, and profit from this information, accordingly.

${ }^{3}$ Short-selling may also represent manipulative rather than informed trading (Henry and Koski 2010).
} 
analyzing short selling around earnings announcements (Lasser et al. 2010) does not identify the exact source of the information advantage. Earnings comprise many line items (revenues, expenses, gain, and losses).

On the other hand, by focusing on firms with RDS, that is, firms with more hidden or costly-to-understand components of earnings, we can refine this idea. RDS pinpoints insider selling to a single component. Moreover, because RDS items and their amounts are not readily discoverable in financial reports and because RDS transactions occur throughout the fiscal year, it is costly for outside investors to analyze RDS. Yet, they are estimable based on complex accounting knowledge of how RDS occurs. In short, the potential use of RDS in shaping stock prices creates an ideal setting to test whether short selling relates to traders' skill and expertise (versus privileged access).

To study the relation between RDS and shorting, we extract from the Markit Security Finance database measures of (i) shorting demand (i.e., short interest, quantity on loan, active utilization of lendable shares) and (ii) shorting supply (i.e., the inventory of lendable shares available for shorting, loan fee). Markit provides a detailed and comprehensive picture of the equity shorting market for its clients by collecting its data from institutional lenders worldwide. We relate Markit's measures of shorting demand and supply to RDS at the next financial statement release date. If short sellers exploit RDS, the sign and amount of RDS should not only relate to shorting demand and supply but, also, foretell future negative excess stock returns when outside investors gradually realize the valuation implications of low or negative RDS after that date.

Our analysis produces five key results. First, we replicate Landsman et al. (2011) and corroborate their result that low or negative RDS associates with lagged negative excess stock returns. However, we also find that the main Landsman et al. (2011) result holds only for stocks with low short interest (a proxy for low shorting demand) before financial statement release date. The negative excess returns 12 months after financial statement release date are, thus, confined to low or negative RDS stocks with low levels of prior short interest. Further investigation also attributes this result to the presence of tighter constraints on lending supply for RDS stocks with high short interest. ${ }^{4}$ Second, having established the mispricing of low or negative RDS stocks for our sample, we find that short sales demand before financial statement release date correlates negatively and significantly with RDS. This implies that shorting demand increases for firms with low or negative RDS. Short sellers expect these firms' stock prices to decline in the future, for example, after investors eventually incorporate RDS into their valuation. Shorting supply, however, does not increase commensurably with shorting demand, arguably making shorting more expensive, especially for low or

\footnotetext{
${ }^{4}$ We further confirm this result by showing that high short interest RDS stocks do not generate significantly negative returns in the 12 months before financial statement release date.
} 
negative RDS stocks. We observe this result as a drop in the supply of lendable shares and an increase in the stock lending fee..$^{5}$

Third, we find stronger patterns of increased shorting demand and decreased shorting supply for low or negative RDS stocks with less readable financial statements. This is consistent with RDS imposing additional information processing effort due to its complexity. Fourth, we repeat our analysis for the major types of RDS in our sample, specifically, transactions relating to (i) share-based mergers and acquisitions (ii) stock option exercises, (iii) pooling method mergers and acquisitions, and (iv) dilutive convertible bonds and stocks. While we do not observe differential increases in demand or reductions in supply across the four different types, our basic result still holds, that low or negative RDS associates with short selling. Fifth, based on an analysis of insiders' transactions, we rule out the possibility that insider trading before the financial statement release date relates significantly to RDS as a correlated confounding factor.

Together, these results support the view that short sellers arbitrage the complexity of RDS. However, because shorting demand increases and shorting supply does not, short sellers are constrained by the supply and cost of shortable stocks to move equity prices quickly toward their lower fundamental values (Beneish et al. 2015). We, thus, contribute to the accounting and finance literature by documenting the role of constrained short selling as an economic mechanism to explain the finding in Landsman et al. (2011) of a gradual negative investor response to low or negative RDS following financial statement release date. In addition, unlike much of the prior literature that focuses on aggregate accounting measures such as net income, sales, expenses, and accruals, we contribute new knowledge by attributing shorting activity to an identifiable, largely hidden component of net income. This is a second important addition to the accounting and finance literature because it links shorting demand to the skill and expertise of a sophisticated trader (i.e., a short seller) who must piece together a firm's deemed RDS items by assessing recognized and disclosed amounts and unrecognized and undisclosed amounts relating to equity transactions at other than fair value.

Our paper proceeds as follows. Section 22 reviews the prior literature and states the hypotheses. Section 3 outlines the research design. Section 4 describes the sample and data. Section 5 presents the results, and Section 6 concludes.

${ }^{5}$ This result is also consistent with Beneish et al. (2015, p. 34), who state that "suppliers of lendable shares (primarily institutions) tend to withdraw from the loan market when ... financial indicators point to overvaluation". 


\section{Literature and hypotheses}

\subsection{Really dirty surplus}

The first strand of literature describes RDS as an hidden element of OCI arising from equity transactions recognized at other than fair value (for background, see Black 2016). As such, RDS violates the super-clean surplus condition that the change in book equity equals net income minus dividends plus net new shares (Christensen and Feltham 2003; Feltham and Ohlson 1995; Ohlson 1995). When financial reporting violates this condition, the carrying value of equity plus the value of future residual income does not match the market value of shares outstanding. RDS is mostly negative because financial statements recognize equity transactions at below fair value. For example, shares issued in a stock option exercise are issued at strike price, almost always below fair value. The primary sources of RDS are from share- or asset-exchange mergers, employee stock option exercises, conversions of preferred stock and debt to common equity, and share offerings and repurchases at other than fair value. Before the implementation of FASB Statement No. 141, the pooling-of-interests method of accounting for business mergers and acquisitions also yielded RDS. If outside investors were to comprehend promptly and unbiasedly the valuation implications of RDS, then it would be impossible for short sellers to implement a profitable trading strategy based on those amounts. To illustrate the presence of RDS, Landsman et al. (2006) use the residual income framework to compare the valuation implications of four approaches to employee stock option accounting. ${ }^{6}$ They show that only fair value recognition of an asset (e.g., prepaid compensation expense) and a liability (e.g., an obligation to issue shares on exercise) at grant date and asset amortization and mark-to-market accounting for the liability results in super-clean surplus accounting. Such fair value recognition, however, violates US GAAP. The other three methods could potentially generate RDS.

RDS seems too complex and costly for outside investors to comprehend fully its valuation implications. Unlike dirty surplus items, which are mostly reported in OCI and do not appear to shape firm valuation (Cahan et al. 2000; Landsman et al. 2011), RDS is not readily observable. It depends on a non-recognized attribute of an equity transaction. Also, as a permanent difference, RDS does not diminish over longer reporting periods. The effort to comprehend the different types and amounts of RDS transactions that can occur throughout the year further aggravates the pricing task of an outside investor. Markets are, thus, less likely to price efficiently RDS transactions than dirty surplus or other reported accounting transactions.

\footnotetext{
${ }^{6}$ APB 25 "recognize nothing", SFAS 123 (revised) "recognize ESO expense”, FASB Exposure Draft "recognize and expense ESO asset" and "recognize ESO asset and ESO liability".
} 


\subsection{Short interest and stock returns}

Three strands of the short interest literature also relate to our study. ${ }^{7}$ First, several papers examine relations between short interest and stock returns, in calendar time and around specific events (Boehmer et al. 2008; Boehmer and Wu 2013; Christophe et al. 2004; Desai et al. 2006; Diether et al. 2009; Kecskés et al. 2012; Pownall and Simko 2005; Senchack and Starks 1993). These papers mostly support the proposition that short sellers trade to exploit an information advantage than to hedge or speculate. However, in a study of shorting around SEO announcements. Henry and Koski (2010) conclude that short selling is driven more by manipulative than informed short sellers. The short interest/stock return relation may also have weakened from increased hedge fund activity (Asquith et al. 2005).

A second strand considers the source of short sellers' information advantage, whether from the skilled analysis of public information or from private access. While some contend that the shorting market is a critical channel for private information revelation (Cohen et al. 2007), others posit that short sellers derive their information advantage from the costly analysis of public information such as earnings announcements (Christophe et al. 2004), firm fundamentals (Dechow et al. 2001; Jiao et al. 2016), and news in general (Engelberg et al. 2012). Others suggest that short sellers have strong reasons to exploit accruals (Bhojraj and Swaminathan 2009; Desai et al. 2006) and questionable accounting disclosures leading to a securities fraud investigation (Griffin 2003; Karpoff and Lou 2010).

Evidence of the precise source of information advantage remains unsettled, however. For example, Griffin and Grundfest (2002) rebut the privileged-access hypothesis, showing that insiders and short traders use similar costly public information around securities litigation events, where short sellers' costly public information derives from superior analysis of company insiders' Form 4 (insider transaction) reports and class action filings. However, Amin and Lee (2010) find that options traders reflect both kinds of informed trading: trading based on access to private information and better analysis of public news and events. In a study of gains from closing large short positions in Japan, Boehmer et al. (2008) also find evidence of both kinds of informed trading, suggesting that the source of advantage may be contextual. This lack of clear evidence on the precise source of short sellers' information advantage helps motivate our study. Because RDS items and their amounts are not readily observable in annual reports, and yet they are deemed estimable based on complex accounting knowledge and costly analysis of how RDS occurs, this creates an ideal setting to illustrate whether short selling relates to traders' skill and expertise (versus privileged

\footnotetext{
${ }^{7}$ Since Jones and Larsen (2008) review the early literature, this section concentrates on the more recent studies of short interest and information content, although we do not claim to provide a comprehensive coverage. See Diether et al. (2009) for a review of the later short interest empirical literature.
} 
access). Specifically, if RDS has the potential for profitable trading by short sellers, we predict that short selling demand will increase in the magnitude of RDS, which is an inverse statistical relation because exploitable RDS is mostly negative.

A third strand examines the effects of constraints and costs on short interest activity. These studies conclude that short selling constraints and costs can lead to overpricing in the equity markets. Topics include the uptick rule (Aitken et al. 1998; Alexander and Peterson 1999), the costs and difficulties of short selling as trade-limiting factors (Berkman et al. 2009; Chen et al. 2002; Jones and Lamont 2002), and other constraints on short selling (Grullon et al. 2015), especially those that restrict the supply of shortable stocks. Beneish et al. (2015) is especially relevant. The authors explain how constraints on shorting supply can act as a predictor of future negative returns. In particular, they show that lenders tend to reduce supply and raise fees when the shares for shorting are the most attractive to the short sellers (the borrowers), which is when demand is highest. In the setting of RDS, we, therefore, predict that because short traders as borrowers of shortable stock expect future negative returns (because unrecognized RDS can lead to overvaluation), knowing this stock lenders will restrict supply and increase borrowing fees so that both parties (stock lenders and stock borrowers) can potentially gain from the transaction. The preceding provides a strong conceptual foundation for our main hypothesis, which we state in two parts in the alternative form as:

H1a: There is a negative relation between RDS and proxies for shorting demand.

$\mathrm{H} 1 \mathrm{~b}$ : There is a positive relation between RDS and proxies for shorting supply.

\subsection{Information processing effort}

A further consideration relates to the hidden nature and complexity of RDS types and amounts. Investors and other sophisticated institutional investors interested in RDS must first access and extract the relevant information from the firm's financial statements and other documents. This is a costly activity. To proxy for the information processing effort associated with RDS, we use the Li (2008) annual report readability score (Fog index). This is constructed from the computational linguistics literature and the length of the document. If RDS results in a less readable financial report by imposing higher information processing costs on outside investors, this may create more favorable arbitrage opportunities for specialists such as short sellers, who have the skill, expertise, and means to decipher RDS at a lower cost. Thus, we expect a stronger relation between RDS and shorting demand and supply for firms whose annual reports are more difficult to read. We state our second hypothesis in the alternative form as:

$\mathrm{H} 2$ : The negative (positive) relation between RDS and shorting demand (supply) in $\mathrm{H} 1$ is stronger for firms with greater information processing effort for outside investors. 


\subsection{Insider trading}

It is natural to assume that other informed investors such as insiders would try to utilize their knowledge of RDS. One source could come from insider's access to non-public information. However, given that regulators and courts regularly investigate insiders' questionable use of non-public information, insiders' use of non-public information would seem especially costly, even for non-public information leaked to agents in expert networks (Pulliam et al. 2010). Insiders, nonetheless, could trade on RDS in the same way as short sellers, based on their skill and expertise in understanding the distinctions among clean, dirty surplus, and RDS accounting. Building on the literature that insider trading reveals hidden information (Cheng and Lo 2006; Cohen et al. 2012; Karpoff and Lee 1991; Lakonishok and Lee 2001), as a rebuttable test, we predict whether net insider acquisitions (buys minus sells) decreases in the magnitude of RDS. The relation may be weak or non-existent, though, because insiders must report their trades promptly, which are then often imitated by outside investors (Lakonishok and Lee 2001), As such, there may be little opportunity for insiders to gain. Fernandes and Ferreira (2009) show that stock prices respond quickly to information gleaned from insider trading. Notwithstanding this result, Khan and Lu (2013) document a significant surge in short

sales right before large insider sales, indicating that short sellers front-run insiders by exploiting their private information. Defining net insider acquisitions as buys minus sells, we state our third hypothesis in the alternative form as follows:

H3: There is a positive relation between RDS and net insider acquisitions.

\section{Research Design}

\subsection{Computation of RDS}

Following others (Chambers et al. 2007; Dhaliwal et al. 1999; Landsman et al. 2006; O'Hanlon and Pope 1999), we define dirty surplus (DS) and RDS as follows. DS equals (i) Marketable securities adjustment (change in Compustat MSA) plus (ii) Retained earnings less Cumulative translation adjustment (change in Compustat RECTA) plus (iii) 0.65 times the change in the difference between Pension-Unrecognized prior service cost and PensionAdditional minimum liability (i.e., min [(Compustat PCUPSO - PDDML), 0]). RDS equals (i) the change in the carrying value of common equity (Compustat CEQ + TSTKP - DVPA) less (ii) DS less (iii) net income (Compustat NI - DVP) plus dividends (Compustat DVC) less (iv) share price at the middle of the fiscal year (from the CRSP database) times the change in common shares outstanding (Compustat CSHO, adjusted for stock dividends and splits). For the regression analysis, we scale RDS by shareholders' equity at the beginning of the year. The scaled variable is labeled as $R D S$ (in italics). 


\subsection{RDS and future excess returns}

We begin by replicating the main result in Landsman et al. (2011). First, we rank firms on market capitalization and assign each firm to a small, medium, or large firm-size group. Second, we assign the firms in each size group to terciles based on RDS. This procedure generates nine portfolios. Third, for each firm in the nine portfolios, we calculate the expected risk-adjusted excess return for all sample years. Fourth, we calculate the hypothetical hedge return for each size portfolio by deducting the top $R D S$ tercile risk-adjusted return from the bottom $R D S$ tercile return. ${ }^{8}$ If investors overreact to low or negative RDS, then we should obtain positive excess returns in this test. Conversely, if investors do not undervalue RDS, then we should not obtain positive excess returns. We follow Carhart (1997) to calculate expected the risk-adjusted excess return for month $t+1$ as of month $t, E R_{i, t+1}$. The time-series regression is:

$$
\begin{aligned}
& E R_{i, t+1}=R_{f, t+1}+\beta_{R M R F, i, t+1}\left(R_{M, t+1}-R_{f, t+1}\right)+\beta_{S M B, i, t+1} S M B_{t+1}+\beta_{H M L, i, t+1} H M L_{t+1} \\
& +\beta_{M O M, i, t+1} M O M_{t+1}
\end{aligned}
$$

where $\beta_{R M R F, i, t+1}, \beta_{S M B, i, t+1}, \beta_{H M L, i, t+1}$, and $\beta_{M O M, i, t+1}$ are firm-specific coefficients estimated from the past 60 months of returns using Eq.(4). $R_{M, t+1}-R_{f, t+1}$, is the monthly return of the market portfolio in excess of the riskfree rate, $S M B_{t+1}, H M L_{t+1}$, and $M O M_{t+1}$ are the size, book-to-market, and momentum factors, respectively. The excess return for firm $i$ in month $t+1$ is the firm's realized return in month $t+1, R_{i, t+1}$, less $E R_{i, t+1}$. In the hedge-return tests, we use 12-months starting three months after fiscal yearend as the holding period. Few short-selling positions last over one year.

Fifth, we extend this framework to examine RDS hedge returns for low and high short interest ratio (SIR) stocks. If investors' response to RDS varies based on shorting demand (as proxied by the mean SIR over 12 months before financial statement release), we should observe that the hedge fund excess returns for each of the small, medium, and large firm-size groups differ similarly based on the SIR split. Outside investors' knowledge of high SIR stocks could prompt an increase in lenders' shorting fee. This would make the short side of a hypothetical hedging strategy of buying (selling) positive (negative) RDS stocks less profitable.

\subsection{Shorting demand and supply regressions}

We use direct measures of shorting demand and shorting supply using the data from Markit. We proxy for shorting demand based on total demand quantity (Total_Balance_Quantity). This is the quantity of shares on loan

\footnotetext{
${ }^{8}$ Note that RDS is typically negative because the accounting processes that generate RDS originate from equity transactions recognized at less than market value. The hedge portfolio strategy thus take a long position in firms with least negative RDS and a short position in firms with most negative RDS.
} 
divided by shares outstanding. For shorting supply, we use inventory quantity (Lendable_Quantity). This is the quantity of stock inventory available to lend divided by shares outstanding. ${ }^{9}$ We also consider loan fee (Loan_Fee), the average of the lowest and the highest securities lending fee for current lending transactions. In the regressions, loan fee is specified as affecting shorting demand and supply. More specifically, to infer the effect of RDS on equity shorting activities, we estimate shorting supply and shorting demand as a function of price (Loan_Fee), a measure of really dirty surplus $(R D S)$, and other controls. We use the instrumental variables proposed by Angrist et al. (2000) and Aggarwal et al. (2015) to examine the price sensitivity of shorting supply and shorting demand. Kolasinski et al. (2013) use a similar methodology to examine the relation between the supply schedule and searching frictions in the equity lending market. If a shorting fee spikes due to a constraint in supply, the higher fees lead to a lower shorting demand. Thus, it is likely that OLS regression models that ignore endogeneity will suffer from downward bias in the estimates of demand changes in response to RDS. Likewise, biased changes in demand can also induce error in the response of equity shorting supply to RDS. Hence, we estimate the following two-stage models by regressing shorting demand and shorting supply on $R D S$ and controls. For shorting demand (Total_Balance_Quantity), the model is:

$$
\begin{aligned}
& \text { 1st stage: Loan_Fee } i=\alpha+\beta_{1} R D S_{i, t}+\sum_{x} \beta_{x} \times \text { Instruments_S }+\sum_{y} \beta_{y} \times \text { Controls }+\sum_{z} \beta_{z} \times Y e a r \_D u m m i e s+ \\
& \text { 2nd stage: Shorting_Demand }{ }_{i, 1}=\alpha+\beta_{1} R D S_{i, t}+\beta_{2} \text {Loan_Fe}_{l, t}+\sum_{y} \beta_{y} \times \text { Controls }+ \\
& \sum_{z} \beta_{z} \times \text { Year_Dummies }+\sum_{m} \beta_{m} \times \text { Month_Dummies }+\sum_{n} \beta_{n} \times \text { Industry_Dummies }+\varepsilon_{t+1} \text {. }
\end{aligned}
$$

For shorting supply (Lendable_Quantity), the model is:

$$
\begin{aligned}
& \text { 1st stage: Loan_Fee } i=\alpha+\beta_{1} R D S_{i, t}+\sum_{x} \beta_{x} \times \text { Instruments_D }+\sum_{y} \beta_{y} \times \text { Controls }+\sum_{z} \beta_{z} \times \text { Year_Dummies }+ \\
& \sum_{m} \beta_{m} \times \text { Month_Dummies }+\sum_{n} \beta_{n} \times \text { Industry_Dummies }+\varepsilon_{t+1} \\
& 2 \text { nd stage: Shorting_Supply }{ }_{i,+1}=\alpha+\beta_{1} R D S_{i, t}+\beta_{2} \text { Loan_Fe } e_{l, t}+\sum_{y} \beta_{y} \times \text { Controls }+ \\
& \quad \sum_{z} \beta_{z} \times \text { Year_Dummies }+\sum_{m} \beta_{m} \times \text { Month_Dummies }+\sum_{n} \beta_{n} \times \text { Industry_Dummies }+\varepsilon_{t+1} .
\end{aligned}
$$

In Eq. (2) and Eq. (3), $t$ is the month of financial statement release and shorting supply and demand are calculated over 12 months before $t$. The non-RDS regressor variables at $t$ in Eq. (2) and Eq. (3) are defined in Table 2. Our main interest is the sign and significance of the $\beta_{1}$ coefficient for $R D S$. The coefficient $\beta_{1}$ represents the average effect of $R D S$ on shorting supply or demand. Consistent with H1a, we predict $\beta_{1}<0$ for the shorting demand regression (Eq. (2)), assuming short sellers arbitrage stocks with larger $R D S$ amounts, which are mostly negative. Consistent with H1b (and Beneish et al. 2015), we predict $\beta_{1}>0$ for Shorting Supply equals Lendable_Quantity (as low or negative RDS should reduce shorting supply) and $\beta_{1}<0$ for Shorting Supply equals Loan_Fee. Low or negative RDS should increase the cost of shorting.

\footnotetext{
${ }^{9}$ In sensitivity tests, we consider other proxies for shorting supply and demand.
} 
The first stage Instruments_D and Instruments_S are the exogenous instruments used to identify Loan_Fee in the second stage for each of the two categories of shorting variables (i.e., Shorting Demand and Shorting Supply). We include year, month, and industry fixed effects in the regression models. Identification requires finding instruments that are exogenously related to Loan_Fee but unrelated to the error term in the second-stage shorting supply and demand equations. To achieve these objectives, we employ two instruments for the shorting supply and the shorting demand equations from following the literature (Aitken et al. 1998; Angrist et al. 2000). Specifically, we instrument lendable supply to represent changes in borrowing demand to control for the endogeneity between quantity and price. We instrument demand to represent changes in lendable supply. Aggarwal et al. (2015) demonstrate that this approach generates instruments that satisfy the exclusion restriction, that the instruments do not impact on the dependent variable either directly or through omitted variables.

We specify shorting supply by employing the following variables to capture demand-related shocks to Loan_Fee: hedging demand. ${ }^{10}$ The choice of hedging demand builds on the idea developed by Hwang et al. (2019). They suggest that equity short selling facilitates the hedging of industry risk, thus reducing the equity underpricing. If the underpricing of other firms in the same industry occurs, arbitrageurs can profit from a trading strategy by buying the under-valued firms and shorting substitute securities. Hence, the shorting demand for shorting stock $i$ is expected to be higher when the demand for going long on the stocks of other firms, $j$, becomes higher. We estimate underpricing as low relative to cumulative returns in the preceding year and compute relative returns as the equal-weighted cumulative return in the preceding 252 days of other firms in the same four-digit SIC industry classifier. This underpricing excludes the firm's returns.

We specify shorting demand by employing institutional ownership concentration (Inst_Conc) as an instrumental variable for Loan_Fee. We expect institutional ownership concentration to relate to loan fee, yet not relate to shorting demand. We measure ownership concentration by using the Hirschman-Herfindahl index. Porras Prado et al. (2016) show that institutional ownership concentration is a key driver of shorting supply even after considering the common proxies for shorting supply such as total institutional ownership. Lendable supply is more significantly impacted by the presence of larger shareholders arising from a more concentrated ownership, since these larger shareholders can have more economic incentive to exert power oversupply. If overpricing occurs from short sale constraints, shareholders may strive to reduce supply to maintain prices of their own shares. Thus, the larger shareholders may

10 While Aggarwal et al. (2015) consider hedging demand, earnings surprise, and discretionary accruals, we use only hedging demand since the latter two instruments are likely to be correlated error terms of the second stage model in our setting. 
choose not to lend stock. Since short-sales strategies use short horizons (Kolasinski et al. 2013), concentrated ownership, which is typically long-term with respect to investment horizon, should not relate to the short-term demand for loans. This makes ownership concentration an ideal candidate for an instrument of shorting supply.

\section{Sample, Data, and Descriptive Statistics}

\subsection{Sample and data}

Our shorting demand and supply variables are from the Markit Security Finance database. The items in Markit include total quantity of stock on loan, percentage of actively lendable securities in lending programs that are currently out on loan (shorting demand scaled by supply), the quantity of lendable shares available for shorting (shorting supply), rebates and fees, number of days to cover the total quantity of stock borrowed in the market, and the cost to borrow the stock charged by the lenders from the prime brokers in the wholesale market. The database also includes dividends, stock splits, and firm identifiers such as ISIN, SEDOL, and CUSIP. We then merge finance and accounting data are from CRSP and Compustat North America with the Markit variables based on CUSIP. Our data cover stock lending during 2002-2012. Our beginning and ending years are constrained by Markit's coverage at the time of availability of the dataset.

Panel A of Table 1 presents the sample distribution by industry, defined according to the Fama and French 48industry classification. Our sample covers a wide range of industries, the most heavily represented being business services (15.65\%), followed by Banking (11.04\%), and Electrical Equipment (6.16\%). Panel B presents the number of sample firms by fiscal year and shows a slight increase over time.

\subsection{Descriptive statistics}

Table 2 presents descriptive statistics for RDS (RDS divided by beginning of year shareholders' equity) and the short-selling variables. Mean and median RDS are -53.209 and -0.404 , respectively, consistent with Landsman et al. (2011). For the shorting-demand variables, SIR and Total_Balance_Quantity, a comparison of the means, of 0.071 and 0.039 , respectively, and medians, of 0.016 and 0.001 , respectively, indicates that these variables are right-skewed. We also employ a relative measure of shorting demand, Active_Utilization, which represents the percentage of shares on loan among the total pool of shares held by lenders. Mean (median) Active_Utilization is 53 percent (15 percent).11 For the lending supply variables, Lendable_Quantity and Loan_Fee, the means of are 0.071 and 6.270, respectively.

\footnotetext{
${ }^{11}$ High lending fees and recall risk are two forces that reduce demand and limit active utilization to less than $100 \%$ (Beneish et al. 2015).
} 
The descriptive statistics for shorting demand and supply in Table 2 are consistent with Beneish et al. (2015), who analyze the same dataset.

\section{Results}

\subsection{Replication}

Landsman et al. (2011) show that RDS associates positively and significantly with risk-adjusted hedge returns for periods following the release of the financial statements. They find that investors do not fully incorporate the implications of RDS into stock prices. Panel A of Table 3 replicates and corroborates that study by summarizing the risk-adjusted stock returns for firms in the top $R D S$ and bottom $R D S$ terciles for all, small, medium, and large firms. The third row of each subgroup in Panel A shows the difference in portfolio risk-adjusted return between the top tercile $R D S$ portfolio and the bottom tercile $R D S$ portfolio. Consistent with Landsman et al. (2011), we find that the excess risk-adjusted returns differ from zero for all firm-size groups, but most prominently for small firms. For the full sample, the one-year excess risk-adjusted return for the bottom tercile (top tercile) portfolio is -3.9 percent (-56.4 percent). The risk-adjusted hedge return is positive (47.4 percent) and significant (t-stat. 7.58). Landsman et al. (2011, p. 253) report a risk-adjusted hedge return of 4.0 percent (t-stat. 5.84).

We next examine whether the hedge returns to RDS in Panel A differ on the basis of shorting activity. Because of the potential for short sellers to gain from RDS-related stock overvaluation, we assume short sellers apply their effort and skill to a wide range of information (e.g., proprietary data, news articles, research reports, regulatory filings, prior financial statements) to estimate deemed RDS before financial statement release date (Desai et al. 2006). We identify stocks each year as low or high SIR stocks split at the sample median each year of SIR measured over 12 months (-11 to 0 ) relative to fiscal yearend month 0 (the financial statement release date). For each high and low SIR portfolio, we then form terciles based on RDS. Panel B of Table 3 shows that the one-year-ahead risk-adjusted hedge portfolio return is positive and significant for the low SIR portfolio. The one-year excess risk-adjusted return for the bottom $R D S$ tercile (top tercile) portfolio is 33.7 percent (-14.2 percent) and the overall risk-adjusted hedge return is positive (47.9\%) and significant ( $t$-stat. 1.72). Panel $\mathrm{C}$ of Table 3, however, indicates that the one-year-ahead riskadjusted hedge return for the high SIR portfolio is not significantly different from zero ( $t$-stat. -0.92).

While one might reason that high SIR stocks should increase hedge returns more than low SIR stocks, the key to understanding this result is whether high SIR stocks are actually those expected to generate negative future excess returns. Beneish et al. (2015) offer and confirm an explanation, documenting that the supply of stocks with high SIR is likely to be constrained. While short borrowers may find them attractive, security lenders, presumably not wanting 
to lose money, restrict the supply of high SIR stocks and increase loan fees. So, for an RDS short seller, the more profitable short side relates to stocks not in high demand, whose supply is more abundant and whose loan fees are lower. Hence, the RDS hedge return strategy results in Table 3 are more predictably positive for low SIR stocks than high SIR stocks.

We also test whether an omitted risk factor might drive the results in Table 3 . To address this issue, we control for two additional risk factors, namely, profitability and investment. The robustness of profitability is measured by the robust factor $(R M W)$ and the degree of investment is measured by the conservative factor $(C M A)$. Fama and French (2015) show that a five-factor model ( $M K T \_R F, S M B, H M L, R M W$, and $\left.C M A\right)$ explains up to 94 percent of the crosssectional variance of stock returns. We test whether our results are robust to this five-factor specification, or a sixfactor specification, which is five factors above plus $M O M$. In an untabulated analysis, we find that regardless of model specification, the hedge return of a high minus low RDS portfolio conditional on low SIR stocks in the portfolio is positive and significant. This result suggests that omitted risk factors are unlikely to explain the hedge portfolio analysis in Table 3 .

\subsection{RDS and loan fee}

Table 4 summarizes the results of estimating Eq. (2) (1 $1^{\text {st }}$ stage), where we regress Loan_Fee on RDS, instrumental variables, and controls. The coefficient of $R D S$ is negative and significant with p-value $<0.01$, consistent with the fee for borrowing stock being higher for firms with higher (more negative) RDS. This result is consistent with those by Duong et al. (2017), documenting that lending fees increase (on the supply side) before negative earnings announcements. They interpret these results in terms of institutional investors pricing their private news in the stock lending market when they acquire adverse information via private channels. They are prohibited from trading before the public release of the information. Similarly, we deduce that institutional investors may signal their private negative news on RDS transactions not by trading directly but increasing the fee for others (short sellers) to trade. Supporting this view, when we include the indicators, RDS_Top and RDS_Bottom, for firm-year observations in the top and the bottom terciles of RDS, respectively, we find an asymmetric effect of RDS. That is, the coefficients on RDS_Top and $R D S \_$Bottom are significantly positive and negative (with $\mathrm{p}$-value $<0.05$ ). These results indicate that the asymmetric effect of RDS on loan fee occurs for firms located at the extreme two tails of RDS distribution. While fees are determined by shorting demand as well as supply, they also appear to play an informational role. That is, lending fees deliver private negative news from the supply side in addition to shorting demand. 


\subsection{RDS and shorting demand and supply}

For shorting demand, our empirical strategy estimates shorting demand (Total_Balance_Quantity) as a function of the simultaneously determined price (Loan_Fee), and a really dirty surplus $(R D S)$, as in Eq. (2) and Eq. (3). In the first stage, we use instruments for shorting demand variables to measure exogenous variation in Loan_Fee.Column 1 of Table 5 gives the first stage estimates for Loan_Fee. In the first stage, we use instruments for shorting demand to measure exogenous changes in Loan_Fee. Columns 2 to 4 of Table 5 summarize our main second-stage results using the instrumented fee from the first stage. All equations include the equity market characteristics specified in the preceding section as control variables, industry, year and month fixed effects, and standard errors clustered by firm. In column 1, the average effects of $R D S$ on loan fee equals $191.55 \%(-53.209 \times-0.0360)$, indicating that RDS firms' shares are subject to a significant increase in lending fees. For the shorting demand regressions, columns $2-4$ of Table 5 indicate that the $\beta_{1}$ coefficients for $R D S$ in Eq. (2) are negative and significant $(\mathrm{p}<0.01)$ for $R D S$ and $R D S \_B o t t o m$. Thus, for more negative RDS (suggestive of current overpricing and future negative returns), the negative coefficient indicates an increase in shorting demand.

Similar to the above, for shorting supply, our empirical strategy estimates shorting supply (Lendable_Quantity) as a function of the simultaneously determined price (Loan_Fee), really dirty surplus (RDS), and controls. Column 5 indicates $\beta_{1}<0(\mathrm{p}<0.01)$. Thus, shorting supply for RDS stocks increases the higher the loan fee. In addition, column 6 indicates $\beta_{1}>0$ (p $\left.>0.01\right)$. Thus, for stocks with low or negative $R D S$, lendable quantity decreases. Thus, similar to Beneish et al. (2015), RDS stocks that are potentially attractive for shorting are either less available or costlier to borrow.

Given the difference in hedge returns for low and high RDS stocks in Panels A and B of Table 3, we categorize the firm-month shorting observations into terciles of $R D S$ and estimate the regressions separately for the lowest and highest $R D S$ terciles. In these regressions, we specify the lowest and highest $R D S$ terciles as indicator variables, that is, a one for an observation in the highest or lowest tercile, otherwise zero. For the lowest $R D S$ tercile, column 4 indicates that $\beta_{1}<0(\mathrm{p}<0.05)$ for the demand regressions, whereas $\beta_{1}>0(\mathrm{p}<0.01)$ for the lendable quantity regression (column 8) and $\beta_{1}<0(\mathrm{p}<0.01)$ for the loan fee regression (column 5). Thus, when shorting is most attractive to short sellers (stocks in the lowest $R D S$ tercile), column 4 indicates that short sellers correctly understand the valuation implications of RDS and increase demand. However, for the most attractive shorting candidates (stocks in the lowest $R D S$ tercile), supply declines (column 8). 
By contrast, column 3 of Table 5 shows that the $\beta_{1}$ coefficients for the highest tercile $R D S$ stocks are significantly positive, consistent with a drop in demand. The negative coefficient for $R D S$ in Column 7 of Table 5 also indicates an increase in shorting supply from RDS but a decrease in loan fee. In other words, it is as if institutions increase shorting supply for highest tercile $R D S$ stocks but there are no takers on the short side. Why? Because the possible returns to highest tercile $R D S$ stocks are more likely to be positive than negative (and thus not attractive for shorting). See, also, Table 3 of this study and Landsman et al. (2011, Table 4).

\subsection{RDS and shorting conditional on information processing effort}

We test here whether the observed association between RDS and shorting differs for high and low information processing effort. Following Li (2008), as a proxy for the readability of firms' annual report, we use the widelyaccepted Fog index, constructed from the computational linguistics literature. We assume that a less-readable report demands more costly information processing effort by an outside investor, creating arbitrage opportunities for skilled short sellers, whose costs are lower. Thus, we predict a stronger relation between RDS and shorting demand and supply for high Fog-index firms. We rank firm-months by Fog score and specify Fog_Dummy an indicator variable for firm-month observations in the top Fog tercile. We then add Fog_Dummy to Eq. (2) and interact this with RDS. Column 2 of Table 6 shows a negative coefficient for RDS x Fog_Dummy, which is indicative of an increase in shorting demand when the financial statements are less readable. Consistent with Table 5, lending supply is also predictably lower $(\mathrm{p}<0.05)$ for low or negative RDS stocks with higher Fog measures. But loan fee is higher too. Thus, for RDS stocks requiring higher information processing effort by outside investors, we observe a stronger positive relation between shorting demand and RDS a stronger negative relation between shorting supply and RDS. These results support $\mathrm{H} 2$.

\subsection{Components of RDS}

Having established that shorting demand increases and shorting supply decreases for low or negative RDS firms, we extend the analysis by investigating the individual types of RDS. If RDS has a common valuation effect, we should observe qualitatively similar results for each type compared to Table 5.12 First, we focus on stock-based merger and acquisition transactions, which are typically consummated with a bidding price being greater than fair price to attract a sufficient number of bidders. Second, we examine mergers recognized as pooling-of-interests, as equity issued under pooling-of-interests gives rise to an unrecorded asset. Third, we study executive stock option exercises. Finally, we

\footnotetext{
${ }^{12}$ Landsman et al. (2011) document that for each of the above RDS types hedge portfolio returns remain significant.
} 
analyze dilutive transactions such as warrants, convertible instruments, and stock options, by computing the difference between basic and diluted earnings per share as a fraction of equity carrying value. We specify dummy variables for the four major types of RDS in our sample: Merger for observations with stock-based merger and acquisitions and onward; Option_Exer for observations with executive-level option exercises and onward; Pooling for firm-month observations with merger of the pooling-of-interest method and onward; and Diluted for observations with equity dilution by convertible bonds, preferred shares, and warranties. The expanded regression model is:

$$
\begin{aligned}
& \text { Shorting Demand or Supply } y_{i, t}=\alpha+\beta_{1} R D S_{t}+\beta_{2} \text { Merger }_{t}+\beta_{3} R D S_{t} x \text { Merger }_{t}+\beta_{4} O p t i o n_{-} \text {Exer }_{t}+\beta_{5} R D S_{t} x \\
& \text { Option_Exer }_{t}+\beta_{6} \text { Pooling }_{t}+\beta_{7} R D S_{t} \times \text { Pooling }_{t}+\beta_{8} \text { Diluted }_{t}+\beta_{9} R D S_{t} \times \text { Diluted }_{t}+\beta_{10 S I Z E_{t}}+\beta_{11} \text { Book-to- } \\
& \text { Market }_{t}+\beta_{12} r_{t-1}+\beta_{13} r_{t-12, t-2}+\beta_{14} \text { Volume }+\sum_{x} \beta_{x} \times \text { Year_Dummies }_{2} \beta_{y} \times \text { Month_Dummies }+ \\
& \sum n \beta_{n} \times \text { Industry_Dummies }+\varepsilon_{t+1} \text {. }
\end{aligned}
$$

The $\beta_{3}, \beta_{5}, \beta_{7}$, and $\beta_{9}$ interaction coefficients in Eq. (4) represent the incremental effect of each individual RDS type on shorting demand and supply. Table 7 summarizes the results and offer the following observations. First, the $\beta$ interaction coefficients in the demand equation vary in sign across the RDS types in the directions predicted in H1a and H1b. For example, the coefficients for RDS $x$ Merger and RDS $x$ Pooling in column 2 for the shorting demand equation are significantly negative, whereas the coefficient for $R D S x$ Diluted is significantly positive. For the supply equation (column 4), we also observe variation in the signs of the interaction coefficients across the different sources of RDS. Nonetheless, the signs of the $\beta_{3}, \beta_{5}, \beta_{7}$, and $\beta_{9}$ interaction coefficients do switch in sign from column 2 to column 4. This is consistent with the main effect of $R D S$, which is has the effect of increasing shorting demand (the $R D S$ coefficient is significantly negative) and decreasing shorting supply (the $R D S$ coefficient is significantly positive).

\subsection{RDS and insider trading}

Insiders form another group of informed traders who may act ahead of outside investors. They may also mimic the trades of short sellers and vice versa. Hence, we need to test for the potential confounding effect of insiders' transactions. We collect insider trading data from the Thomson Reuters Insiders Database. The database classifies each trading activity as an acquisition (A) or disposition (D). For example, open market purchases and stock option exercises are acquisitions, and open market sales are dispositions. To implement our test, we first calculate net acquisitions by insiders as A minus D divided by shares outstanding as of financial statement release date. ${ }^{13}$ We then

\footnotetext{
${ }^{13}$ As the largest part of acquisition or disposition is open market purchases or sales, we also examine net purchases instead of net acquisitions. The net purchases figure is calculated from only open market purchases and sales. We find little difference by switching from net acquisitions to net purchases.
} 
calculate net acquisitions over months -8 to 3 around financial statement release month 0 as a proxy for insider trading before outside investors potentially understand the RDS in financial statements. We also follow the methodology of Cohen et al. (2012) to distinguish routine insider trades from nonroutine insider trades. To test for insider trading effects, we regress net insider acquisitions on $R D S$ and the same control variables in Eq. (2). The results in Table 8 indicate that $R D S$ does not explain net insider acquisitions either for all transactions (column 1) or nonroutine transactions (column 2). However, the positive coefficient signs in columns 1 and 2 are "correct" in that we might expect insiders to reflect more sales than purchases in low or negative RDS stocks. Such stock prices are more likely to depreciate in the future (Table 3 and Landsman et al. 2011, Table 4). Nonetheless, RDS has no significant predictive ability for insider trading and, thus, would not appear to confound our evidence of a link between RDS and shorting. In short, this evidence does not support H3.

\section{Conclusion}

We examine in this study whether shorting demand and supply associate with RDS. RDS is a hidden element of comprehensive net income that occurs when financial statements do not reflect the fair value of certain equity transactions. Arguing that outside investors do not fully comprehend the valuation implications of RDS, researchers have shown that the stock price adjustment to RDS occurs gradually following the release of financial statements. Informed investors with knowledge of RDS, however, could potentially exploit this gradual price adjustment. Reflecting the activities of one group of informed investors, namely, short sellers, we find that short selling demand and supply vary predictably with firms' RDS. Moreover, we find that shorting occurs even before RDS is discoverable from firms' financial statements. This implies that short sellers find it attractive to exploit RDS for trading purposes. Our paper is important in at least two respects. First, our findings imply that short sellers expend effort to arbitrage a particularly complex and costly-to-process element of financial statements. This result contributes to the accounting and finance literature because most studies of short selling around accounting variables examine aggregates such as earnings, sales, accruals, other news items, rather than pinpoint a particular component of these items. Second, we resolve the open question raised at the outset of why the excess returns of low or negative RDS stocks following the financial statement release date still exist despite the actions of informed investors such as short sellers. The answer lies in the fact that short sellers face market constraints. Specifically, our evidence shows that securities lenders reduce the supply of stock available for shorting and charge higher fees to the short sellers as securities borrowers when RDS

levels are more attractive for shorting. Accordingly, short sellers cannot fully utilize their informational advantage due to limits to arbitrage. Overall, our evidence suggests that while the trades of short sellers associate strongly with 
RDS information hidden in financial statements, short sellers' actions are unable to complete price discovery due to shorting market constraints. As such, prices continue to drift in response to RDS following financial statement release date. A policy implication of our findings is that with fewer constraints or frictions, short selling would hasten price discovery regarding difficult-to-understand accounting disclosures.

\section{References}

Aggarwal, R., P. A. C. Saffi, and J. Sturgess. 2015. The Role of Institutional Investors in Voting: Evidence from the Securities Lending Market. The Journal of Finance 70 (5):2309-2346.

Aitken, M. J., A. Frino, M. S. McCorry, and P. L. Swan. 1998. Short Sales Are Almost Instantaneously Bad News: Evidence from the Australian Stock Exchange. The Journal of Finance 53 (6):2205-2223.

Alexander, G. J., and M. A. Peterson. 1999. Short Selling on the New York Stock Exchange and the Effects of the Uptick Rule. Journal of Financial Intermediation 8 (1):90-116.

Amin, K. I., and C. M. C. Lee. 2010. Option Trading, Price Discovery, and Earnings News Dissemination. Contemporary Accounting Research 14 (2):153-192.

Angrist, J. D., K. Graddy, and G. W. Imbens. 2000. The Interpretation of Instrumental Variables Estimators in Simultaneous Equations Models with an Application to the Demand for Fish. The Review of Economic Studies 67 (3):499-527.

Asquith, P., P. A. Pathak, and J. R. Ritter. 2005. Short interest, institutional ownership, and stock returns. Journal of Financial Economics 78 (2):243-276.

Beneish, M. D., C. M. C. Lee, and D. C. Nichols. 2015. In short supply: Short-sellers and stock returns. Journal of Accounting and Economics 60 (2):33-57.

Beneish, M. D., and M. E. Vargus. 2002. Insider trading, earnings quality, and accrual mispricing. The Accounting Review 77 (4):755-791.

Berkman, H., V. Dimitrov, P. C. Jain, P. D. Koch, and S. Tice. 2009. Sell on the news: Differences of opinion, short-sales constraints, and returns around earnings announcements. Journal of Financial Economics 92 (3):376-399.

Bhojraj, S., and B. Swaminathan. 2009. How does the corporate bond market value capital investments and accruals? Review of Accounting Studies 14 (1):31-62.

Biddle, G. C., and J.-H. Choi. 2006. Is Comprehensive Income Useful? Journal of Contemporary Accounting \& Economics 2 (1):1-32.

Black, D. E. 2016. Other comprehensive income: a review and directions for future research. Accounting \& Finance $56(1): 9-45$.

Boehmer, E., C. M. Jones, and X. Zhang. 2008. Which shorts are informed? The Journal of Finance 63 (2):491-527.

Boehmer, E., and J. Wu. 2013. Short Selling and the Price Discovery Process. The Review of Financial Studies 26 (2):287-322.

Cahan, S. F., S. M. Courtenay, P. L. Gronnewoller, and D. R. Upton. 2000. Value Relevance of Mandated Comprehensive Income Disclosures. Journal of Business Finance \& Accounting 27 (9 - 10):1233-1265.

Carhart, M. M. 1997. On Persistence in Mutual Fund Performance. The Journal of Finance 52 (1):57-82.

Chambers, D., T. J. Linsmeier, C. Shakespeare, and T. Sougiannis. 2007. An evaluation of SFAS No. 130 comprehensive income disclosures. Review of Accounting Studies 12 (4):557-593.

Chen, J., H. Hong, and J. C. Stein. 2002. Breadth of ownership and stock returns. Journal of Financial Economics 66 (2):171-205.

Cheng, Q., and K. Lo. 2006. Insider Trading and Voluntary Disclosures. Journal of Accounting Research 44 (5):815-848.

Christensen, P. O., and G. Feltham. 2003. Economics of Accounting: Information in Markets, New York: Springer Science+Business Media.

Christophe, S. E., M. G. Ferri, and J. J. Angel. 2004. Short-Selling Prior to Earnings Announcements. The Journal of Finance 59 (4):1845-1876.

Christophe, S. E., M. G. Ferri, and J. Hsieh. 2010. Informed trading before analyst downgrades: Evidence from short sellers. Journal of Financial Economics 95 (1):85-106.

Cohen, L., K. B. Diether, and C. J. Malloy. 2007. Supply and Demand Shifts in the Shorting Market. The Journal of Finance 62 (5):2061-2096. 
Cohen, L., C. Malloy, and L. Pomorski. 2012. Decoding Inside Information. The Journal of Finance 67 (3):10091043.

Curtis, A., and N. L. Fargher. 2014. Does Short Selling Amplify Price Declines or Align Stocks with Their Fundamental Values? Management Science 60 (9):2324-2340.

D'Avolio, G. 2002. The market for borrowing stock. Journal of Financial Economics 66 (2-3):271-306.

Dechow, P. M., A. P. Hutton, L. Meulbroek, and R. G. Sloan. 2001. Short-sellers, fundamental analysis, and stock returns. Journal of Financial Economics 61 (1):77-106.

Desai, H., S. Krishnamurthy, and K. Venkataraman. 2006. Do short sellers target firms with poor earnings quality? Evidence from earnings restatements. Review of Accounting Studies 11 (1):71-90.

Dhaliwal, D., K. R. Subramanyam, and R. Trezevant. 1999. Is comprehensive income superior to net income as a measure of firm performance? Journal of Accounting and Economics 26 (1):43-67.

Diether, K. B., K.-H. Lee, and I. M. Werner. 2009. Short-Sale Strategies and Return Predictability. The Review of Financial Studies 22 (2):575-607.

Dowdell, T. D., S. Kim, and S. Lim. 2018. Do Financial Analysts Fully Incorporate the Future Earnings Implications of Really Dirty Surplus into Their Earnings Forecasts? Canadian Academic Accounting Association (CAAA) Annual Conference https://ssrn.com/abstract=3101498.

Duong, T. X., Z. R. Huszár, R. S. K. Tan, and W. Zhang. 2017. The Information Value of Stock Lending Fees: Are Lenders Price Takers?*. Review of Finance 21 (6):2353-2377.

Engelberg, J. E., A. V. Reed, and M. C. Ringgenberg. 2012. How are shorts informed?: Short sellers, news, and information processing. Journal of Financial Economics 105 (2):260-278.

Fama, E. F., and K. R. French. 2015. A five-factor asset pricing model. Journal of Financial Economics 116 (1):122.

Feltham, G. A., and J. A. Ohlson. 1995. Valuation and Clean Surplus Accounting for Operating and Financial Activities. Contemporary Accounting Research 11 (2):689-731.

Fernandes, N., and M. A. Ferreira. 2009. Insider Trading Laws and Stock Price Informativeness. The Review of Financial Studies 22 (5):1845-1887.

Griffin, P. A. 2003. A league of their own? Financial analysts' responses to restatements and corrective disclosures. Journal of Accounting, Auditing \& Finance 18 (4):479-517.

Griffin, P. A., and J. A. Grundfest. 2002. When does insider selling support a "strong inference" of fraud? AsiaPacific Journal of Accounting \& Economics 9 (2):159-207.

Grullon, G., S. Michenaud, and J. P. Weston. 2015. The Real Effects of Short-Selling Constraints. The Review of Financial Studies 28 (6):1737-1767.

Henry, T. R., and J. L. Koski. 2010. Short Selling Around Seasoned Equity Offerings. The Review of Financial Studies 23 (12):4389-4418.

Hirshleifer, D., S. H. Teoh, and J. J. Yu. 2011. Short arbitrage, return asymmetry, and the accrual anomaly. The Review of Financial Studies 24 (7):2429-2461.

Hwang, B.-H., B. Liu, and W. Xu. 2019. Arbitrage Involvement and Security Prices. Management Science 65 (6):2858-2875.

Jiao, Y., M. Massa, and H. Zhang. 2016. Short selling meets hedge fund 13F: An anatomy of informed demand. Journal of Financial Economics 122 (3):544-567.

Jones, C. M., and O. A. Lamont. 2002. Short-sale constraints and stock returns. Journal of Financial Economics 66 (2-3):207-239.

Jones, S. L., and G. Larsen, Jr. . 2008. The Information Content of Short Sales. In Handbook of Finance, F.J. Fabozzi (Ed.). doi:10.1002/9780470404324.hof001016.

Karpoff, J. M., and D. Lee. 1991. Insider trading before new issue announcements. Financial Management:18-26.

Karpoff, J. M., and X. Lou. 2010. Short Sellers and Financial Misconduct. The Journal of Finance 65 (5):18791913.

Kecskés, A., S. A. Mansi, and A. Zhang. 2012. Are short sellers informed? Evidence from the bond market. The Accounting Review 88 (2):611-639.

Khan, M., and H. Lu. 2013. Do Short Sellers Front-Run Insider Sales? The Accounting Review 88 (5):1743-1768.

Kolasinski, A. C., A. V. Reed, and M. C. Ringgenberg. 2013. A Multiple Lender Approach to Understanding Supply and Search in the Equity Lending Market. The Journal of Finance 68 (2):559-595.

Lakonishok, J., and I. Lee. 2001. Are Insider Trades Informative? The Review of Financial Studies 14 (1):79-111.

Landsman, W. R., B. L. Miller, K. Peasnell, and S. Yeh. 2011. Do Investors Understand Really Dirty Surplus? The Accounting Review 86 (1):237-258.

Landsman, W. R., K. V. Peasnell, P. F. Pope, and S. Yeh. 2006. Which approach to accounting for employee stock options best reflects market pricing? Review of Accounting Studies 11 (2-3):203-245. 
Lasser, D., X. Wang, and Y. Zhang. 2010. The effect of short selling on market reactions to earnings announcements. Contemporary Accounting Research 27 609-638.

Li, F. 2008. Annual report readability, current earnings, and earnings persistence. Journal of Accounting and Economics 45 (2):221-247.

O'Hanlon, J. F., and P. F. Pope. 1999. The Value-Relevance of UK Dirty Surplus Accounting Flows. The British Accounting Review 31 (4):459-482.

Ohlson, J. A. 1995. Earnings, Book Values, and Dividends in Equity Valuation. Contemporary Accounting Research 11 (2):661-687.

Porras Prado, M., P. A. C. Saffi, and J. Sturgess. 2016. Ownership Structure, Limits to Arbitrage, and Stock Returns: Evidence from Equity Lending Markets. The Review of Financial Studies 29 (12):3211-3244.

Pownall, G., and P. J. Simko. 2005. The Information Intermediary Role of Short Sellers. The Accounting Review 80 (3):941-966.

Pulliam, S., M. Rothfeld, J. Strasburg, and G. Zuckerman. 2010. U.S. in vast insider trading probe. The Wall Street Journal.

Reed, A. V. 2015. Connecting supply, short-sellers and stock returns: Research challenges. Journal of Accounting and Economics 60 (2-3):97-103.

Senchack, A. J., and L. T. Starks. 1993. Short-Sale Restrictions and Market Reaction to Short-Interest Announcements. The Journal of Financial and Quantitative Analysis 28 (2):177-194. 
Table 1 Sample distribution

\begin{tabular}{lrrlrl}
\hline Panel A: Sample Distribution by Industry & & & & & \\
\hline & & & & & \\
Fama-French 48 Indy. & Frequency & Percent & Miscellaneous (48) & 1,787 & 0.64 \\
Agriculture (1) & 734 & 0.26 & Nonmetallic Mining (28) & 787 & 0.28 \\
Aircraft (24) & 1,466 & 0.52 & Personal Services (33) & 176 & 0.06 \\
Alcoholic Beverages (4) & 639 & 0.23 & Petroleum and Natural Gas & 10,351 & 3.69 \\
Apparel (10) & 2,921 & 1.04 & $(30)$ & & \\
Automobiles and Trucks & 3,110 & 1.11 & Pharmaceutical Products & 13,406 & 4.78 \\
(23) & & & (13) & & \\
Banking & 30,956 & 11.04 & Precious Metals (27) & 417 & 0.15 \\
Business Services (34) & 43,870 & 15.65 & Printing and Publishing (8) & 1,550 & 0.55 \\
Business Supplies (38) & 2,413 & 0.86 & Real Estate & 1,687 & 0.6 \\
Candy and Soda (3) & 1,031 & 0.37 & Recreational Products (6) & 2,089 & 0.75 \\
Chemicals (14) & 4,800 & 1.71 & Restaurants & 4,681 & 1.67 \\
Coal & 715 & 0.26 & Retail (42) & 13,509 & 4.82 \\
Computers (35) & 7,330 & 2.61 & Rubber and Plastic & 1,169 & 0.42 \\
Construction Materials & 6,795 & 2.42 & Products (15) & & \\
(17) & & & Ship Building, Railroad & 693 & 0.25 \\
Consumer Goods (9) & 3,466 & 1.24 & Equipment (25) & & \\
Defense (26) & 605 & 0.22 & Shipping Containers (39) & 680 & 0.24 \\
Electrical Equipment (22) & 17,277 & 6.16 & Steel Works, Etc. (19) & 3,526 & 1.26 \\
Electronic Equipment (36) & 3,920 & 1.4 & Telecommunications (32) & 5,039 & 1.8 \\
Fabricated Products (20) & 616 & 0.22 & Textiles (16) & 761 & 0.27 \\
Food Products (2) & 3,039 & 1.08 & Tobacco Products (5) & 268 & 0.1 \\
Insurance & 9,319 & 3.32 & Trading & 20,364 & 7.26 \\
Machinery (21) & 9,197 & 3.28 & Transportation (40) & 7,902 & 2.82 \\
Measuring and Control & 5,622 & 2.01 & Utilities (31) & 1,102 & 3.96 \\
Equipment (37) & & & Wholesale (41) & 9,865 & 3.52 \\
Medical Equipment (12) & 8,724 & 3.11 & Total & 280,374 & 100.00 \\
\cline { 2 - 5 } & & & & &
\end{tabular}

Panel B: Sample Distribution by Year

\begin{tabular}{lrr}
\hline Fiscal year & No. of sample firms & Percent \\
\hline 2002 & 162 & 0.06 \\
2003 & 6,148 & 2.19 \\
2004 & 11,836 & 4.22 \\
2005 & 25,910 & 9.24 \\
2006 & 31,145 & 11.11 \\
2007 & 34,397 & 12.27 \\
2008 & 33,683 & 12.01 \\
2009 & 34,042 & 12.14 \\
2010 & 34,121 & 12.17 \\
2011 & 34,142 & 12.18 \\
2012 & 34,788 & 12.41 \\
\hline \multicolumn{3}{c}{} \\
\hline
\end{tabular}


Table 2 Descriptive statistics

\begin{tabular}{|c|c|c|c|c|c|c|}
\hline & $\mathrm{N}$ & Mean & Q1 & Median & Q3 & $\overline{\text { Std. dev. }}$ \\
\hline$\overline{R D S}$ & 280,374 & -53.209 & -11.583 & -0.404 & 2.488 & 273.014 \\
\hline Total_Balance_Quantity & 280,374 & 0.039 & 0.000 & 0.001 & 0.005 & 0.174 \\
\hline Lendable_Quantity & 280,374 & 0.071 & 0.012 & 0.067 & 0.119 & 0.058 \\
\hline Loan_Fee & 280,374 & 6.270 & 5.518 & 6.129 & 6.841 & 1.474 \\
\hline Size & 280,374 & 13.306 & 12.071 & 13.280 & 14.533 & 1.801 \\
\hline Book-to-Market & 280,374 & 0.715 & 0.341 & 0.560 & 0.868 & 0.626 \\
\hline$r_{t-1}$ & 280,374 & 0.008 & -0.056 & 0.006 & 0.068 & 0.120 \\
\hline$r_{t-12, t-2}$ & 280,374 & 0.100 & -0.163 & 0.052 & 0.280 & 0.444 \\
\hline Volume & 280,374 & 0.002 & 0.001 & 0.001 & 0.002 & 0.002 \\
\hline
\end{tabular}

The sample consists of 280,374 firm-month observations over a sample period of 2002-2012 that satisfy the data requirements. $R D S$ is RDS divided by the beginning of fiscal year carrying value of shareholders' equity. SIR is short interest ratio, computed as the number of shorted shares scaled by the number of outstanding shares. Total_Balance_Quantity is total quantity of stock on loan scaled by the number of outstanding shares. Active_Utilization is the percentage of actively lendable securities in lending programs which are currently out on loan, calculated as the value of assets on loan from lenders divided by the active lendable value. Lendable_Quantity is quantity of stock inventory, available to lend scaled by the number of outstanding shares. Loan_Fee is the average of the lowest and the highest securities lending fee for current lending transactions. Size is the natural log of a firm's total market capitalization (in millions). Book-to-Market is the ratio of the carrying value of equity at the end of the year to market value of equity. $r_{t-1}$ is Stock return for month $t-1 . r_{t-12, t-2}$ is stock return from month $t-12$ to $t-2$. Volume is average daily share turnover during the previous six months adjusted by the average daily exchange turnover. 
Table 3 Portfolio returns by RDS

\begin{tabular}{lrr}
\hline & & Four-Factor-Risk-Adjusted \\
& $\begin{array}{r}\text { Stock Return: } \\
\end{array}$ & MLT_RF, SMB, HML, MOM \\
\hline Panel A Overall sample & & -0.564 \\
Bottom 30\% & -0.039 \\
Top 30\% & 240.366 & $0.474 * * *$ \\
Hedge Return & $(7.58)$ \\
t-stat. & & $<.0001$ \\
Empirical p-value (two-sided) & & -0.142 \\
Panel B Low SIR subgroup & 0.337 \\
Bottom 30\% & -41.924 & $0.479 *$ \\
Top 30\% & 9.075 & $(1.72)$ \\
Hedge Return & & $<.0001$ \\
t-stat. & & \\
Empirical p-value (two-sided) & & 0.550 \\
Panel C High SIR subgroup & & 0.847 \\
Bottom 30\% & & 0.297 \\
Top 30\% & -28.359 & $(0.92)$ \\
Hedge Return & 6.589 & 0.355 \\
t-stat. & & \\
Empirical p-value (two-sided) & & \\
\hline
\end{tabular}

Every calendar year, we rank stocks into three groups by market value at the end of the year. Panel A ranks the overall sample. Panel B ranks stocks in the low SIR sample. Panel C ranks stocks in the high SIR sample. We identify stocks as low or high SIR stocks split at the sample median each year of SIR measured over 12 months (-11 to 0$)$ relative to fiscal yearend month 0 (financial statement release date). For each market-value group, we form terciles based on RDS. We take the low RDS rank (rank 1) and the high RDS rank (rank 3), and take an equally-weighted average of individual monthly stock returns by rank. The individual stock returns are measured over months 3 to 15 months, where month 0 is the fiscal yearend month. We regress the monthly portfolio return in excess of risk-free rate on the Fama French three-factors plus the momentum factor. The regression method is OLS with a heteroscedasticity consistent error structure. The hedge return is computed by deducting the mean risk-adjusted return for the bottom three deciles portfolio from that for the top three deciles portfolios. The strategy implementation begins three months after the firm's fiscal yearend. $t$-stats are in the parentheses. Statistically significant coefficients at the $1 \%, 5 \%$, and $10 \%$ level are marked as $* * *, * *$, and $*$, respectively. 
Table 4 Regressions of loan fee on RDS and controls

\begin{tabular}{|c|c|c|c|}
\hline \multirow{2}{*}{$\begin{array}{l}\text { Dep. } \text { Variable }= \\
\text { Model }\end{array}$} & \multicolumn{3}{|c|}{ Loan_Fee } \\
\hline & $(1)$ & $(2)$ & (3) \\
\hline$R D S$ & $\begin{array}{r}-0.0359 * * * \\
(2.71)\end{array}$ & & \\
\hline RDS_Top & & $\begin{array}{r}0.0825 * * \\
(-2.31)\end{array}$ & \\
\hline RDS_Bottom & & & $\begin{array}{r}-0.0508 * * \\
(2.07)\end{array}$ \\
\hline Hedging_Demand & $\begin{array}{r}0.0227 \\
(0.18)\end{array}$ & $\begin{array}{r}0.0224 \\
(0.18)\end{array}$ & $\begin{array}{r}0.0193 \\
(0.16)\end{array}$ \\
\hline Inst_Conc & $\begin{array}{r}-1.5698^{*} \\
(-1.66)\end{array}$ & $\begin{array}{r}-1.5870^{*} \\
(-1.68)\end{array}$ & $\begin{array}{r}-1.5727 * \\
(-1.67)\end{array}$ \\
\hline Equity Market characteristics & & & \\
\hline Size & $\begin{array}{r}-0.0501^{*} \\
(-1.69)\end{array}$ & $\begin{array}{r}-0.0559^{*} \\
(-1.88)\end{array}$ & $\begin{array}{r}-0.0604 * * \\
(-2.04)\end{array}$ \\
\hline Book-To-Market & $\begin{array}{r}-0.1623 * * * \\
(-4.90)\end{array}$ & $\begin{array}{r}-0.1614 * * * \\
(-4.84)\end{array}$ & $\begin{array}{r}-0.1647 * * * \\
(-4.92)\end{array}$ \\
\hline$r-1$ & $\begin{array}{r}0.2916^{* *} \\
(2.09)\end{array}$ & $\begin{array}{r}0.2812 * * \\
(2.03)\end{array}$ & $\begin{array}{r}0.2768^{* *} \\
(1.97)\end{array}$ \\
\hline$r-12,-2$ & $\begin{array}{r}-0.2013 * * * \\
(-5.95)\end{array}$ & $\begin{array}{r}-0.2151 * * * \\
(-5.81)\end{array}$ & $\begin{array}{r}-0.2132 * * * \\
(-6.33)\end{array}$ \\
\hline Volume & $\begin{array}{r}133.9368 * * * \\
(6.43)\end{array}$ & $\begin{array}{r}136.9433 * * * \\
(6.57)\end{array}$ & $\begin{array}{r}135.3802 * * * \\
(6.56)\end{array}$ \\
\hline Spread & $\begin{array}{r}-0.8608 * * * \\
(-3.75)\end{array}$ & $\begin{array}{r}-0.8702 * * * \\
(-3.77)\end{array}$ & $\begin{array}{r}-0.8664 * * * \\
(-3.74)\end{array}$ \\
\hline Price_5 & $\begin{array}{r}0.1399 \\
(1.46)\end{array}$ & $\begin{array}{r}0.1307 \\
(1.38)\end{array}$ & $\begin{array}{r}0.1321 \\
(1.37)\end{array}$ \\
\hline Retvol & $\begin{array}{r}8.3931 * * * \\
(5.13)\end{array}$ & $\begin{array}{r}8.4895 * * * \\
(5.17)\end{array}$ & $\begin{array}{r}8.4135 * * * \\
(5.15)\end{array}$ \\
\hline Inst & $\begin{array}{r}-0.9108 * * * \\
(-6.15)\end{array}$ & $\begin{array}{r}-0.8997 * * * \\
(-6.05)\end{array}$ & $\begin{array}{r}-0.8992 * * * \\
(-6.06)\end{array}$ \\
\hline $\begin{array}{l}\text { Asymmetry between } \\
\text { RDS_Top \& RDS_Bottom }\end{array}$ & & & $\begin{array}{r}0.1333 * * * \\
(3.17)\end{array}$ \\
\hline Industry fixed effects & Yes & Yes & Yes \\
\hline Year \& Month fixed effects & Yes & Yes & Yes \\
\hline Adj. $R_{2}$ & 0.421 & 0.421 & 0.421 \\
\hline$\underline{\mathrm{N}}$ & 244,477 & 244,477 & 244,477 \\
\hline
\end{tabular}

This table reports the results of estimating Eq. (2)(first stage), which regresses Loan_Fee on RDS and controls. RDS is RDS divided by the beginning of fiscal year carrying value of equity. Column 1 estimates Eq. (2) for RDS as a continuous variable. Columns 2 and 3 specify the lowest and highest RDS terciles as indicator variables, that is, a one for the highest tercile (RDS_Top) or lowest tercile (RDS_Bottom), otherwise zero. Loan_Fee is the average of the lowest and the highest securities lending fee for current lending transactions. Table 2 states the definitions of the other control variables. $* * *, * *$, and $*$ indicate significance at $0.01,0.05$, and 0.10 level, respectively (one-tailed when the sign of coefficients are predicted, otherwise, two-tailed). 
Table 5 Regressions of shorting supply and demand on RDS and controls

\begin{tabular}{|c|c|c|c|c|c|c|c|c|}
\hline \multirow[b]{3}{*}{ Dep. Variable $=$} & \multicolumn{4}{|c|}{ Shorting Demand } & \multicolumn{4}{|c|}{ Shorting Supply } \\
\hline & 1st Stage & & 2nd Stage & & 1st Stage & & 2nd Stage & \\
\hline & Loan_Fee & $\begin{array}{r}\text { Total_Balance } \\
\text { Quantity }\end{array}$ & $\begin{array}{r}\text { Total_Balance } \\
\text { Quantity }\end{array}$ & $\begin{array}{r}\text { Total_Balance_ } \\
\text { Quantity }\end{array}$ & Loan_Fee & $\begin{array}{r}\text { Lendable } \\
\text { Quantity }\end{array}$ & $\begin{array}{r}\text { Lendable_} \\
\text { Quantity }\end{array}$ & $\begin{array}{r}\text { Lendable } \\
\text { Quantity }\end{array}$ \\
\hline Model & (1) & (2) & (3) & (4) & (5) & (6) & (7) & $(8)$ \\
\hline$\overline{R D S}$ & $\begin{array}{r}-0.0360 \\
(11.92)^{* * *}\end{array}$ & $\begin{array}{r}-6.5665 \\
(-1.97) * *\end{array}$ & & & $\begin{array}{r}-0.0358 \\
(11.86)^{* * *}\end{array}$ & $\begin{array}{r}0.1366 \\
(7.56)^{* * *}\end{array}$ & & \\
\hline$R D S \_T o p$ & & & $\begin{array}{l}14.2581 \\
(2.06)^{* *}\end{array}$ & & & & $\begin{array}{r}-0.2706 \\
(-6.87) * * *\end{array}$ & \\
\hline RDS_Bottom & & & & $\begin{array}{r}-9.4572 \\
(-2.17)^{* *}\end{array}$ & & & & $\begin{array}{r}0.1551 \\
(5.37)^{* * *}\end{array}$ \\
\hline Predicted_Loan_Fee & & $\begin{array}{r}203.3430 \\
(2.22)^{* *}\end{array}$ & $\begin{array}{r}205.2953 \\
(2.46)^{* *}\end{array}$ & $\begin{array}{l}232.5965 \\
(2.75) * * *\end{array}$ & & $\begin{array}{r}-3.1893 \\
(-7.57)^{* * *}\end{array}$ & $\begin{array}{r}-3.1539 \\
(-7.65)^{* * *}\end{array}$ & $\begin{array}{r}-3.1822 \\
(-7.58)^{* * *}\end{array}$ \\
\hline Equity Market characteristics & & & & & & & & \\
\hline Size & $\begin{array}{r}-0.0503 \\
(-24.19)^{* * *}\end{array}$ & $\begin{array}{l}8.8293 \\
(1.91)^{*}\end{array}$ & $\begin{array}{l}10.0001 \\
(2.11)^{* *}\end{array}$ & $\begin{array}{l}12.3514 \\
(2.35)^{* *}\end{array}$ & $\begin{array}{r}-0.0500 \\
(-24.03)^{* * *}\end{array}$ & $\begin{array}{r}-0.2088 \\
(-9.39)^{* * * *}\end{array}$ & $\begin{array}{r}-0.2289 \\
(-9.52) * * *\end{array}$ & $\begin{array}{r}-0.2439 \\
(-9.27)^{* * *}\end{array}$ \\
\hline Book-to-Market & $\begin{array}{r}-0.1629 \\
(-34.55)^{* * *}\end{array}$ & $\begin{array}{r}24.0779 \\
(1.61)\end{array}$ & $\begin{array}{r}24.2416 \\
(1.79)^{*}\end{array}$ & $\begin{array}{l}29.3112 \\
(2.15)^{* *}\end{array}$ & $\begin{array}{r}-0.1626 \\
(-34.48)^{* * *}\end{array}$ & $\begin{array}{r}-0.2935 \\
(-4.18)^{* * *}\end{array}$ & $\begin{array}{r}-0.2851 \\
(-4.17)^{* * *}\end{array}$ & $\begin{array}{r}-0.3004 \\
(-4.24)^{* * *}\end{array}$ \\
\hline$r_{-1}$ & $\begin{array}{r}0.2910 \\
(13.78)^{* * *}\end{array}$ & $\begin{array}{l}-63.6440 \\
(-2.34)^{* *}\end{array}$ & $\begin{array}{r}-62.3411 \\
(-2.59)^{* * *}\end{array}$ & $\begin{array}{r}-69.2583 \\
(-3.02)^{* * *}\end{array}$ & $\begin{array}{r}0.2944 \\
(14.01)^{* * *}\end{array}$ & $\begin{array}{r}0.8544 \\
(6.02) * * *\end{array}$ & $\begin{array}{r}0.8070 \\
(5.95)^{* * * *}\end{array}$ & $\begin{array}{r}0.8013 \\
(5.90)^{* * *}\end{array}$ \\
\hline$r_{-12,-2}$ & $\begin{array}{r}-0.2024 \\
(-30.91)^{* * * *}\end{array}$ & $\begin{array}{r}31.1498 \\
(1.72)^{*}\end{array}$ & $\begin{array}{r}33.9990 \\
(1.92)^{*}\end{array}$ & $\begin{array}{l}39.4191 \\
(2.13)^{* *}\end{array}$ & $\begin{array}{r}-0.1983 \\
(-32.50)^{* * *}\end{array}$ & $\begin{array}{r}-0.6490 \\
(-7.53) * * *\end{array}$ & $\begin{array}{r}-0.6901 \\
(-7.67)^{* * *}\end{array}$ & $\begin{array}{r}-0.6901 \\
(-7.58)^{* * *}\end{array}$ \\
\hline Volume & $\begin{array}{r}134.6898 \\
(66.91)^{* * * *}\end{array}$ & $\begin{array}{r}-18,152.4863 \\
(-1.48)\end{array}$ & $\begin{array}{r}-18,943.6035 \\
(-1.65)^{*}\end{array}$ & $\begin{array}{r}-22,379.3125 \\
(-1.90)^{*}\end{array}$ & $\begin{array}{r}134.6898 \\
(67.16)^{* * * *}\end{array}$ & $\begin{array}{l}482.1411 \\
(8.42)^{* * * *}\end{array}$ & $\begin{array}{l}487.5262 \\
(8.50)^{* * * *}\end{array}$ & $\begin{array}{l}486.1754 \\
(8.43)^{* * *}\end{array}$ \\
\hline Spread & $\begin{array}{r}-0.8599 \\
(-45.10)^{* * *}\end{array}$ & $\begin{array}{r}162.1510 \\
(2.06)^{* * *}\end{array}$ & $\begin{array}{r}165.5063 \\
(2.28)^{* * *}\end{array}$ & $\begin{array}{l}188.4598 \\
(2.63) * * *\end{array}$ & $\begin{array}{r}-0.8598 \\
(-45.11)^{* * * *}\end{array}$ & $\begin{array}{r}-3.4930 \\
(-9.51)^{* * *}\end{array}$ & $\begin{array}{r}-3.4955 \\
(-9.62)^{* * *}\end{array}$ & $\begin{array}{r}-3.5069 \\
(-9.53) * * *\end{array}$ \\
\hline Price_5 & $\begin{array}{r}0.1389 \\
(15.28)^{* * *}\end{array}$ & $\begin{array}{r}-21.9160 \\
(-1.71)^{*}\end{array}$ & $\begin{array}{r}-20.5280 \\
(-1.82)^{*}\end{array}$ & $\begin{array}{r}-24.3898 \\
(-1.78)^{*}\end{array}$ & $\begin{array}{r}0.1407 \\
(15.49)^{* * *}\end{array}$ & $\begin{array}{r}0.0588 \\
(0.89)\end{array}$ & $\begin{array}{r}0.0210 \\
(0.34)\end{array}$ & $\begin{array}{r}0.0299 \\
(0.48)\end{array}$ \\
\hline Retvol & $\begin{array}{r}8.4484 \\
(57.78)^{* * *}\end{array}$ & $\begin{array}{r}-1,181.0061 \\
(-1.53)\end{array}$ & $\begin{array}{r}-1,214.4935 \\
(-1.72)^{*}\end{array}$ & $\begin{array}{r}-1,432.5758 \\
(-2.15)^{* *}\end{array}$ & $\begin{array}{r}8.4393 \\
(57.72)^{* * *}\end{array}$ & $\begin{array}{r}22.9036 \\
(6.37)^{* * *}\end{array}$ & $\begin{array}{r}22.9311 \\
(6.44)^{* * * *}\end{array}$ & $\begin{array}{r}22.9252 \\
(6.38)^{* * * *}\end{array}$ \\
\hline Inst & $\begin{array}{r}-0.9120 \\
(-81.68)^{* * *}\end{array}$ & $\begin{array}{r}129.3706 \\
(1.55)\end{array}$ & $\begin{array}{r}129.1160 \\
(1.73)^{*}\end{array}$ & $\begin{array}{r}153.6517 \\
(2.02)^{* *}\end{array}$ & $\begin{array}{r}-0.9141 \\
(-81.88)^{* * *}\end{array}$ & $\begin{array}{r}-0.9741 \\
(-2.52)^{* *}\end{array}$ & $\begin{array}{r}-0.9006 \\
(-2.41)^{* *}\end{array}$ & $\begin{array}{r}-0.9255 \\
(-2.44)^{* *}\end{array}$ \\
\hline Hedging_Demand & $\begin{array}{r}0.0218 \\
(1.97)^{* *}\end{array}$ & & & & & & & \\
\hline Inst_Conc & & & & & $\begin{array}{r}-1.5819 \\
(-7.82)^{* * *}\end{array}$ & & & \\
\hline Asymmetry between & & & & -23.7153 & & & & 0.4257 \\
\hline RDS_Top \& RDS_Bottom & & & & $(-2.95)^{* * *}$ & & & & $(8.84)^{* * *}$ \\
\hline Partial F-Statistic & 89.92 & $(<0.0001)$ & & & 563.46 & $(<0.0001)$ & & \\
\hline Under-identification test & 3.88 & $(<0.05)$ & & & 61.16 & $(<0.0001)$ & & \\
\hline Weak Identification Test & 3.87 & $(<0.05)$ & & & 61.13 & $(<0.0001)$ & & \\
\hline Endogeneity Test & & $44.88(<0.0001)$ & $\begin{array}{r}44.89 \\
(<0.0001)\end{array}$ & $\begin{array}{r}43.56 \\
(<0.0001)\end{array}$ & & $542.26(<0.0001)$ & $541.69(<0.0001)$ & $542.43(<0.0001)$ \\
\hline Industry fixed effects & Yes & Yes & Yes & Yes & Yes & Yes & Yes & Yes \\
\hline Year \& Month fixed effects & Yes & Yes & Yes & Yes & Yes & Yes & Yes & Yes \\
\hline F-Statistic & 1885.42 & 37.71 & 62.01 & 1355.48 & 1726.85 & 116.46 & 105.56 & 103.80 \\
\hline $\mathrm{N}$ & 244,477 & 244,477 & 244,477 & 244,477 & 244,477 & 244,717 & 244,477 & 244,717 \\
\hline
\end{tabular}

This table reports the results of estimating Eq. (2) and Eq. (3), which regress shorting supply and demand on $R D S$ and controls. $R D S$ is RDS divided by the beginning of fiscal year carrying value of equity. Column 2 estimates Eq. (2) for RDS as a continuous variable. Columns 3 and 4 specify the lowest and highest $R D S$ terciles as indicator variables, that is, a one for the highest tercile (RDS_Top) or lowest tercile (RDS_Bottom), otherwise zero. Total_Balance_Quantity is total quantity of stock on loan scaled by the number of outstanding shares. Lendable_Quantity is quantity of stock inventory, available to lend scaled by the number of outstanding shares.Loan_Fee is the average of the lowest and the highest securities lending fee for current lending transactions. Table 2 states the definitions of the other control variables. $* * *, * *$, and $*$ indicate significance at $0.01,0.05$, and 0.10 level, respectively (one-tailed when the sign of coefficients are predicted, otherwise, two-tailed). 
Table 6 Shorting demand and supply and RDS: Effects of information processing costs

\begin{tabular}{|c|c|c|c|c|}
\hline & \multicolumn{2}{|c|}{ Shorting Demand } & \multicolumn{2}{|c|}{ Shorting Supply } \\
\hline & 1st Stage & 2nd Stage & 1st Stage & 2nd Stage \\
\hline Dep. variable & Loan_Fee & $\begin{array}{r}T_{\text {Total_Balance_ }} \\
\text { Quantity }\end{array}$ & Loan_Fee & $\begin{array}{r}\text { Lendable } \\
\text { Quantity }\end{array}$ \\
\hline Model & $(1)$ & (2) & (3) & (4) \\
\hline$R D S$ & $\begin{array}{r}0.0267 \\
(3.16) * * *\end{array}$ & $\begin{array}{r}-0.7731 \\
(-2.01)^{* *}\end{array}$ & $\begin{array}{r}0.0267 \\
(3.15) * * *\end{array}$ & $\begin{array}{r}-0.0062 \\
(-0.80)\end{array}$ \\
\hline Fog_Dummy & & $\begin{array}{r}-1.1084 \\
(-1.14)\end{array}$ & & $\begin{array}{r}-0.0316 \\
(-4.02)^{* * * *}\end{array}$ \\
\hline RDS x Fog_Dummy & & $\begin{array}{r}-0.7685 \\
(-2.05)^{* *}\end{array}$ & & $\begin{array}{r}0.0180 \\
(2.79)^{* * *}\end{array}$ \\
\hline Predicted_Loan_Fee & & $\begin{array}{r}58.9230 \\
(2.85)^{* * *}\end{array}$ & & $\begin{array}{r}0.5203 \\
(1.62)\end{array}$ \\
\hline Firm-level controls & Yes & Yes & Yes & Yes \\
\hline Industry fixed effects & Yes & Yes & Yes & Yes \\
\hline Year \& Month fixed effects & Yes & Yes & Yes & Yes \\
\hline F-Statistic & 1331.50 & 12441.08 & 1254.59 & 1233.97 \\
\hline $\mathrm{N}$ & 162,759 & 162,759 & 162,759 & 162,759 \\
\hline
\end{tabular}

This table reports the results of estimating Eq. (2) with the addition of Fog_Dummy and RDS x Fog_Dummy as regressor variables. RDS is RDS divided by the beginning of fiscal year carrying value of equity. Fog_Dummy is an indicator for firm-month observations with their Fog index in the top tercile. Total_Balance_Quantity is the total quantity of stock on loan scaled by the number of outstanding shares. Lendable_Quantity is the quantity of stock inventory, available to lend scaled by the number of outstanding shares. Loan_Fee is the average of the lowest and the highest securities lending fee for current lending transactions. Table 2 states the definitions of the other control variables. $* * * * *$, and $*$ indicate significance at $0.01,0.05$, and 0.10 level, respectively (one-tailed when the sign of coefficients are predicted, otherwise, two-tailed). 
Table 7 Shorting demand and supply and RDS: Tests of different RDS types

\begin{tabular}{|c|c|c|c|c|}
\hline & \multicolumn{3}{|c|}{ Shorting Demand } & \multirow{2}{*}{$\begin{array}{c}\text { Shorting Supply } \\
\text { 2nd Stage } \\
\end{array}$} \\
\hline & 1st Stage & Stage & 1st Stage & \\
\hline \multirow[b]{2}{*}{ Dep. variable } & \multicolumn{2}{|c|}{ Total_Balance_ } & \multirow[b]{2}{*}{ Loan_Fee } & Lendable \\
\hline & Loan_Fee & Quantity & & Quantity \\
\hline Model & $(1)$ & $(2)$ & (3) & $(4)$ \\
\hline \multirow[t]{2}{*}{$R D S$} & 0.0360 & -13.3068 & 0.0358 & 0.1834 \\
\hline & $(4.78)^{* * *}$ & $(-1.75)^{*}$ & $(4.75)^{* * *}$ & $(3.30) * * *$ \\
\hline \multirow[t]{2}{*}{ Merger } & & -2.1571 & & 0.0760 \\
\hline & & $(-1.88)^{*}$ & & $(3.49) * * *$ \\
\hline \multirow[t]{2}{*}{ RDS x Merger } & & -1.5150 & & 0.0179 \\
\hline & & $(-2.54) * *$ & & $(1.60)$ \\
\hline \multirow[t]{2}{*}{ Option_Exer } & & -2.9869 & & 0.1843 \\
\hline & & $(-1.94)^{*}$ & & $(5.69) * * *$ \\
\hline \multirow[t]{2}{*}{ RDS x Option_Exer } & & 0.2193 & & -0.0018 \\
\hline & & $(0.13)$ & & $(-0.09)$ \\
\hline \multirow[t]{2}{*}{ Pooling } & & -7.1653 & & 0.0025 \\
\hline & & $(-3.11) * * *$ & & $(0.38)$ \\
\hline \multirow[t]{2}{*}{ RDS $x$ Pooling } & & -1.1139 & & 0.0118 \\
\hline & & $(-0.87)$ & & $(1.73)^{*}$ \\
\hline \multirow[t]{2}{*}{ Diluted } & & -6.2731 & & 0.0181 \\
\hline & & $(-3.15) * * *$ & & $(1.22)$ \\
\hline \multirow[t]{2}{*}{ RDS $x$ Diluted } & & 3.4210 & & -0.0634 \\
\hline & & $(3.05)^{* * *}$ & & $(-2.70)^{* * *}$ \\
\hline \multirow[t]{2}{*}{ Predicted_Loan_Fee } & & 320.4865 & & -3.0877 \\
\hline & & $(1.75)^{*}$ & & $(-2.83)^{* * *}$ \\
\hline Firm-level controls & Yes & Yes & Yes & Yes \\
\hline Industry fixed effects & Yes & Yes & Yes & Yes \\
\hline Year \& Month fixed effects & Yes & Yes & Yes & Yes \\
\hline F-Statistic & 1608.70 & 2587.43 & 8969.11 & 18104.82 \\
\hline $\mathrm{N}$ & 244,477 & 244,477 & 244,477 & 244,477 \\
\hline
\end{tabular}

This table reports the results of estimating Eq. (4), which regresses shorting supply and demand on RDS, indicator variables for four RDS components (defined below) interacted with $R D S$, and controls. RDS is RDS divided by the beginning of fiscal year carrying value of equity. Total_Balance_Quantity is the total quantity of stock on loan scaled by the number of outstanding shares. Lendable_Quantity is the quantity of stock inventory, available to lend scaled by the number of outstanding shares. Loan_Fee is the average of the lowest and the highest securities lending fee for current lending transactions. Merger is an indicator for the firm-month observations with stock-based merger and acquisition and onward. Option_Exer is an indicator for the firm-month observations with executive-level option exercises and onward. Pooling is an indicator for the firm-month observations with merger of the pooling-of-interest method and onward. Diluted is an indicator for the firm-month observations with equity dilution by convertible bond and preferred shares, warranties and others. Table 2 states the definitions of the other control variables. ***,**, and $*$ indicate significance at $0.01,0.05$, and 0.10 level, respectively (one-tailed when the sign of coefficients are predicted, otherwise, two-tailed). 
Table 8. RDS and net insider acquisitions

\begin{tabular}{|c|c|c|}
\hline Dep. variable $=$ & $\begin{array}{c}\text { Net Acquisitions_Pre (all } \\
\text { transactions) }\end{array}$ & $\begin{array}{c}\text { Net Acquisitions_Pre } \\
\text { (nonroutine transactions) }\end{array}$ \\
\hline Model & (1) & (2) \\
\hline$R D S$ & $\begin{array}{r}0.0014 \\
(1.39)\end{array}$ & $\begin{array}{r}0.0013 \\
(1.32)\end{array}$ \\
\hline Size & $\begin{array}{r}0.0023 * * * \\
(4.81)\end{array}$ & $\begin{array}{r}0.0024 * * * \\
(5.02)\end{array}$ \\
\hline Book-to-Market & $\begin{array}{r}-0.0453 \\
(-0.34)\end{array}$ & $\begin{array}{r}-0.0168 \\
(-0.13)\end{array}$ \\
\hline$r_{-1}$ & $\begin{array}{r}-0.0056 \\
(-0.55)\end{array}$ & $\begin{array}{r}-0.0069 \\
(-0.68)\end{array}$ \\
\hline$r-12,-2$ & $\begin{array}{r}-0.1290 * * * \\
(-3.45)\end{array}$ & $\begin{array}{r}-0.1300 * * * \\
(-3.48)\end{array}$ \\
\hline Volume & $\begin{array}{r}-4.9025^{* *} \\
(-2.47)\end{array}$ & $\begin{array}{r}-4.8739 * * \\
(-2.46)\end{array}$ \\
\hline Industry fixed effects & Yes & Yes \\
\hline Year \& Month fixed effects & Yes & Yes \\
\hline Adj. $R^{2}$ & 0.01 & 0.01 \\
\hline $\mathrm{N}$ & 129,540 & 129,540 \\
\hline
\end{tabular}

This table reports results of regressing net insider acquisitions on $R D S$ and controls. Net insider acquisitions is the difference between all acquisition transactions and all disposal transactions, normalized by number of shares outstanding. The key independent variable is $R D S$ and the controls are the same as Eq. (2). Net Acquisitions_Pre indicates net acquisitions by insiders over months -8 to 3 relative to month 0 (release month of financial statements). Insider data is from the Thomson Reuters Database. The nonroutine transactions variable is measured after taking out the repeated insider transactions. Cohen et al. (2012) show that such repeated transactions contain little information. Table 2 states the definitions of the other control variables. $* * *, * *$, and * indicate significance at $0.01,0.05$, and 0.10 level, respectively (one-tailed when the sign of coefficients are predicted, otherwise, two-tailed). 